\title{
Shifts in composition of avian communities related to temperate-grassland afforestation in southeastern South America
}

\author{
Rafael A. Dias ${ }^{1,2}$, Vinicius A. G. Bastazini², Maycon S. S. Gonçalves ${ }^{1}$, \\ Felipe C. Bonow ${ }^{1} \&$ Sandra C. Müller ${ }^{2}$
}

\begin{abstract}
1. LABECO, Universidade Católica de Pelotas, Rua Félix da Cunha 412, 96010-000, Pelotas, RS, Brazil. (rafael_antunes_dias@yahoo.com.br; mayconsanyvan@gmail.com; fbonow@gmail.com) 2. Programa de Pós-Graduação em Ecologia, Instituto de Biociências, Universidade Federal do Rio Grande do Sul, Av. Bento Gonçalves 9500, 91501-970, Porto Alegre, RS, Brazil. (bastazini.vinicius@gmail.com; sandra.muller@ufrgs.br)
\end{abstract}

\begin{abstract}
Afforestation of temperate grasslands with fast-growing trees for industrial pulpwood production is spreading in South America Despite high afforestation rates resulting from governmental policies that stimulate pulpwood production in grasslands of southern Brazil and Uruguay, the impact of this activity on biodiversity remains to be properly assessed. We used an Impact-Reference study design to evaluate how grassland afforestation affects the composition of grassland bird assemblages. We sampled eucalyptus plantations and neighboring natural grasslands in southern Brazil from 2006-2009, and relied on nested sampling and analysis to separate the effects of afforestation from the natural variability of grasslands. We recorded a significant difference in composition between assemblages from grasslands and tree plantations. Species adapted to open, treeless areas tended to be negatively affected in relation to edge or forest birds in eucalyptus plantations. Afforestation is systematically replacing the bird assemblage of hilltop grasslands by a collection of common edge and forest species that occur in nearby riverine and hillside forests. Although most grassland birds negatively affected by tree plantations are common and widespread, observed and predicted afforestation rates in southeastern South America may result in regional population reductions in the near future.
\end{abstract}

KEYWORDS. Río de la Plata Grasslands, pulpwood, Impact-Reference, eucalyptus, Brazil.

RESUMO. Alterações na composição de comunidades de aves relacionadas ao florestamento de campos temperados no sudeste da América do Sul. O florestamento de campos temperados com árvores de crescimento rápido para a produção industrial de celulose está aumentando na América do Sul. Apesar das elevadas taxas de florestamento resultantes de políticas governamentais que estimulam o plantio de árvores para celulose em campos do sul do Brasil e Uruguai, o impacto dessa atividade sobre a biodiversidade ainda carece de avaliação adequada. Utilizamos um delineamento experimental do tipo impacto-referência para avaliar como o florestamento dos campos afeta a composição da assembleia de aves campestres. Amostramos plantações de eucalipto e campos nativos no sul do Brasil entre 2006-2009 e nos valemos de amostragem e análise aninhada para separar os efeitos do florestamento da variabilidade natural dos campos. Registramos uma diferença significativa na composição entre as assembleias de aves do campo e de plantações de eucalipto. Espécies adaptadas a áreas abertas destituídas de árvores foram afetadas negativamente pelo florestamento, ao passo que aves florestais ou de borda de floresta foram favorecidas pela plantação de eucalipto. $\mathrm{O}$ florestamento está sistematicamente substituindo a assembleia de aves de campos de topos de morros por uma coleção de espécies de floresta e de borda comuns em matas ciliares e de encosta. Apesar de a maioria das espécies campestres afetadas negativamente pelas plantações de árvores serem comuns e de ampla distribuição, as taxas de florestamento observadas e previstas no sudeste da América do Sul podem gerar reduções populacionais regionais num futuro próximo.

PALAVRAS-CHAVE. Campos do Rio da Prata, celulose, Impacto-Referência, eucalipto, Brasil.

Habitat loss and degradation are the main drivers of biodiversity loss (Groom \& VynNe, 2006). These factors affect biodiversity via the elimination, displacement or modification of populations of native and invasive species, altering the structure of communities and ecosystems (Groom \& VynNe, 2006). Since habitat loss usually reduces niche availability, ecologically specialized taxa with narrow niche requirements are expected to be at greater risk of extinction than generalists (Owens \& BennetT, 2000; Butler et al., 2007). Traits shared by species that are negatively affected by habitat loss, degradation and fragmentation include low mobility, low fecundity and recruitment, and narrow niche requirements, whereas well-distributed invasive taxa and habitat-generalists are usually listed as winners in altered landscapes (BeISSINGER, 2000; Groom \& VynNe, 2006; Noss et al., 2006).

Habitat loss and degradation have been severe in temperate grasslands, especially in the vast Río de la Plata Grasslands of southeastern South America, which have lost nearly $60 \%$ of the original cover (SORIANO et al., 1992; Henwood, 2010; AzPIroz et al., 2012). The remaining grasslands are located mostly in the northern part of the region, especially in the campos unit of northeastern Argentina, Uruguay and southern Brazil (Vega et al., 2009). Traditionally used for livestock grazing, an activity compatible with conservation if properly managed (DEveley et al., 2008; CASTILHOS et al., 2009), the campos are currently under assault from the expansion of agriculture and commercial forestry (Overbeck et al., 2007; Vega et al., 2009). Only 0.2\% of the campos are protected (HeNwoOd, 2010), an alarming situation considering that these grasslands are highly biodiverse and harbor many threatened and endemic taxa (Overbeck et al., 2007; BencKe, 2009; BOLDRINI, 2009; AZPIROZ et al., 2012).

Small groves of eucalyptus and pines planted for shade and lumber have been a common feature in the campos since the mid-XIXth century (HASSE, 2006). Large-scale afforestation began in the 1980s, when large pulpwood companies were attracted to the region by governmental tax benefits and financial subsidies (CARRERE \& LOHMANN, 1996; HASSE, 2006; VihervaARA et al., 2012). In Uruguay and southern Brazil, where 
land officially offered for afforestation coincided with grassland remnants, environmental licensing processes were controversial and embedded in ideological disputes (Carrere \& Lohmann, 1996; Hasse, 2006; Gautreau \& VÉLEZ, 2011). Currently, tree plantations cover approximately $1,120,000$ ha in the campos of Uruguay and the Brazilian state of Rio Grande do Sul (GaUtreaU \& VéLEZ, 2011).

Plantation forests can be of conservation value in deforested regions, especially when managed to promote stand structural complexity and landscape heterogeneity that benefit forest organisms suffering from habitat loss, edge effects and connectivity breakdown (BROCKERHOFF et al., 2008). In natural grassland areas, however, afforestation is detrimental (BROCKERHOFF et al., 2008). Major biotic impacts on afforested grasslands are changes in abundance, diversity and composition of species assemblages in response to alterations in environmental conditions and disruption of ecological processes (Allan et al., 1997; CORLEY et al., 2006; BUSCARDO et al., 2008; LANTSCHNER et al., 2008; BERTHRONG et al., 2009).

Despite the increase in the number and extent of commercial tree plantations in South America, the impact of this activity on grassland biodiversity remains to be properly assessed. Our main goal was to evaluate how afforestation affects the composition of grassland bird assemblages. We proposed that afforestation has a press (sustained) impact (sensu BENDER et al., 1984) on grassland faunal assemblages. Consequently, we predicted that bird assemblages in grasslands and tree plantations would be structurally different. We also expected that species that are strictly adapted to grassland habitats would be negatively affected in relation to forest and edge birds. Our sampling design and analytical procedures were devised to disentangle the effects of afforestation from natural variability, allowing us to adequately measure anthropogenic impact. This is the first study to use this approach to quantify changes in faunal assemblages following temperate-grassland afforestation.

\section{MATERIAL AND METHODS}

Study area. Our study area spanned $4,918 \mathrm{~km}^{2}$ in southern Rio Grande do Sul, Brazil's southernmost state (Tab. I). Most of our sites are located in the Planalto Sul-Rio-Grandense, an upland system of eroded granite hills, with a few located in the gently rolling terrain of the neighboring Depressão Central sedimentary region (IBGE, 1986). Climate is subhumid; mean annual temperature and precipitation in the region are $16-18^{\circ} \mathrm{C}$ and 1,200-1,400 $\mathrm{mm}$, respectively (IBGE, 1986).

In this region, grasslands predominate on flat or gently rolling terrain (IBGE, 1986; OvERBECK et al., 2007). Natural forest occurs mostly in valleys, especially in the northeastern sector of our study area (IBGE,
1986). Gallery forests occur along most watercourses, and marshes cover floodplains and swales (IBGE, 1986). Herbaceous and shrubby vegetation predominates in grasslands, with Poaceae, Asteraceae, Rubiaceae and Leguminosae being the main families (BOLDRINI, 2009). Scattered trees and bushes are common in the Planalto Sul-Rio-Grandense grasslands. Cattle, sheep and horse ranching are the main economic activity.

The eucalyptus plantations sampled for this study were established in 2004-2006. Eucalyptus trees were planted in hilltop grasslands hitherto used for cattle grazing. Moister grasslands in swales and drainages were not afforested, in accordance with Brazilian environmental law. Stands were of different sizes, limited by roads and watercourses. The Sydney blue gum Eucalyptus saligna Smith (Myrtaceae) and the flooded gum Eucalyptus grandis Hill ex Maiden (Myrtaceae) were the main species cultivated. Plants were spaced 3.0 x $2.0 \mathrm{~m}$ apart. Herbicides and insecticides were applied in the first year. After seven years, trees are cut and new saplings planted.

Experimental design. Since the plantations were established before we had access to the area, we used an Impact-Reference study design (sensu WIENS \& PARKER, 1995). In this scheme, samples are taken at a single time within the impacted area, and from nearby areas that were not impacted and constitute references (WIENS \& PARKER, 1995). Despite being less powerful and having reduced causal inference ability when compared to $\mathrm{BACI}$ or Beyond-BACI designs that rely on 'before and after impact' information (UNDERWOOD, 1994; WIENS \& PARKER, 1995), post-impact tests have been widely used to assess differences between impact and reference sites (see Benedetti-Cecchi \& Osio, 2007).

The plantations covered a broad area, enabling us to rely on nested sampling design and analysis (sensu UNDERwood, 1997) to separate the effects of afforestation from natural variability in reference areas. This peculiar spatial distribution also relieved us from using an asymmetrical analysis to avoid pseudoreplication (UNDERWOOD, 1994; GLASBY, 1997).

Our design consisted of two treatments (afforestation and grassland) replicated at 11 sites. At each site we allocated five $500 \times 100 \mathrm{~m}$ plots per treatment, and counted birds in them. Our sample consisted of 55 impact plots from eucalyptus stands, and 55 reference plots from grasslands.

We only sampled natural hilltop grasslands used for livestock grazing, avoiding pastures planted with exotic grasses. All eucalyptus stands were $2-3$ years old with trees 4-6 m tall. We used a systematic sampling design, choosing the location of the first plot on a map and determining the starting point of subsequent plots at 700-m intervals to ensure independence (HURLBERT, 1984). On many occasions, however, this distance was altered to ensure that plots lay fully within a fenced grassland section or eucalyptus stand. When this 
occurred, a minimum distance of $200 \mathrm{~m}$ between plots was always respected. Grassland plots were at least 200 $\mathrm{m}$ from the nearest eucalyptus stand and natural forest patches. Distances were determined with a hand-held GPS with a 5-m error.

Bird sampling. Sampling was carried out from 2006-2009 (Tab. I). To conform to the premises of the study design and avoid detection bias, we sampled each site only once, in November-December, the peak of the breeding season of the local avifauna (BELTON, 1994). Birds are vocal and restricted to their territories during this period, favoring detection and minimizing chances of double-counting individuals (BIBBY et al., 1992). Counts were carried out by two observers walking at a constant speed along the central line of the plot. Each observer was responsible for searching a $500 \times 50 \mathrm{~m}$ half-section of the plot. We counted all birds that were seen or heard. Individuals in flight were omitted. To favor detection, counts were made in the early morning or late afternoon, in good weather conditions (BIBBY et al., 1992).

Habitat use of birds was defined according to Belton (1994) and Vickery et al. (1999). Threat categories followed IUCN (2011) and scientific nomenclature followed REMSEN et al. (2011).

Statistical analyses. We employed permutational analysis of variance using the pseudo F-ratio as test criterion (Pillar \& Orlóci, 1996; ANDERson, 2001) to evaluate if differences in the composition of bird assemblages between treatments were significant. We used the Bray-Curtis distance between sampling units. Our null hypothesis was that there was no difference in composition between impact and reference areas. Our nested design allowed us to partition the total variation within three factors: among treatments, among sites and among plots. Since our main interest was to understand the effect of afforestation, we blocked both nested factors (sites and plots) to remove the effect of spatial variability from our treatments. We then divided the total sum of squares by the sum of squares between treatments, to determine the proportion of variation explained exclusively by treatments. In both tests we ran 10,000 iterations and adopted an alpha level of 0.05 to consider differences significant.

To determine species positively and negatively affected by grassland afforestation, we relied on a classification method developed to determine habitat specialists and generalists (CHAZDON et al., 2011). This method uses a multinomial model based on estimated species relative abundance in two habitats, to classify species into four categories: (1) generalists, (2) specialists of habitat "a", (3) specialists of habitat "b", and (4) species too rare to classify (CHAZDON et al., 2011). Major advantages of this method include the classification of habitat specialists and generalists without the a priori exclusion of rare species, and the capability of distinguishing habitat generalists (species with no significant habitat affinity) from species that are simply too rare to classify (CHAZDON et al., 2011). Following recommendations by CHAZDON et al. (2011), we set the specialization threshold $K$ to 0.667 and the $P$ level to 0.005 . We assumed that species classified as grassland specialists would be negatively affected by afforestation, whereas eucalyptus specialists would be favored.

Classification of specialist and generalist species was performed on CLAM (CHAO \& LIN, 2011), whereas permutational analysis of variance were carried out on MULTIV 2.63 statistical software (PILlar, 2007).

\section{RESULTS}

We recorded 994 individuals and 57 species in grasslands, and 442 individuals and 54 species in

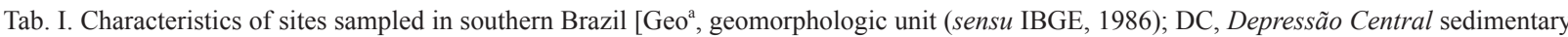
region; PSRG, Planalto Sul-Rio-Grandense uplands].

\begin{tabular}{|c|c|c|c|c|c|}
\hline Site & Municipality & Coordinates & Altitude (m) & $\mathrm{Geo}^{\mathrm{a}}$ & Sampling date \\
\hline Fazenda Seival & Candiota & $\begin{array}{l}31^{\circ} 21^{\prime} 11^{\prime \prime} \mathrm{S}, \\
53^{\circ} 42^{\prime} 53^{\prime \prime} \mathrm{W}\end{array}$ & 315 & DC & Dec 2007 \\
\hline Fazenda Silveiras & Pinheiro Machado & $\begin{array}{l}31^{\circ} 31^{\prime} 34^{\prime \prime} \mathrm{S} \\
53^{\circ} 33^{\prime} 22^{\prime \prime} \mathrm{W}\end{array}$ & 255 & PSRG/DC & Dec 2008 \\
\hline Fazenda São José & Pinheiro Machado & $\begin{array}{l}31^{\circ} 35^{\prime} 30^{\prime \prime} \mathrm{S}, \\
53^{\circ} 33^{\prime} 51^{\prime \prime} \mathrm{W}\end{array}$ & 280 & PSRG/DC & Dec 2007 \\
\hline Fazenda da Ferraria & Piratini & $\begin{array}{l}31^{\circ} 43^{\prime} 18^{\prime \prime} \mathrm{S} \\
53^{\circ} 00^{\prime} 34^{\prime \prime} \mathrm{W}\end{array}$ & 130 & PSRG & Dec 2006 \\
\hline $\begin{array}{l}\text { Fazenda N. Sra. de } \\
\text { Guadalupe }\end{array}$ & Capão do Leão & $\begin{array}{l}31^{\circ} 47^{\prime} 16^{\prime \prime} \mathrm{S}, \\
52^{\circ} 39^{\prime} 08^{\prime \prime} \mathrm{W}\end{array}$ & 85 & PSRG & Nov 2007 \\
\hline Fazenda Santa Heloísa & Pedras Altas & $\begin{array}{l}31^{\circ} 49^{\prime} 38^{\prime \prime} \mathrm{S} \\
53^{\circ} 35^{\prime} 59^{\prime \prime} \mathrm{W}\end{array}$ & 300 & PSRG & Dec 2007 \\
\hline Fazenda São Francisco & Pedras Altas & $\begin{array}{l}31^{\circ} 54^{\prime} 47^{\prime \prime} \mathrm{S} \\
53^{\circ} 37^{\prime} 08^{\prime \prime} \mathrm{W}\end{array}$ & 200 & PSRG & Dec 2006 \\
\hline Fazenda do Bote & Herval & $\begin{array}{l}32^{\circ} 03^{\prime} 10^{\prime \prime} \mathrm{S}, \\
53^{\circ} 30^{\prime} 41^{\prime \prime} \mathrm{W}\end{array}$ & 230 & PSRG & Dec 2006 \\
\hline Fazenda Recanto dos Paz & Arroio Grande & $\begin{array}{l}32^{\circ} 07^{\prime} 15^{\prime \prime} \mathrm{S} \\
52^{\circ} 55^{\prime} 46^{\prime \prime} \mathrm{W}\end{array}$ & 50 & PSRG & Dec 2008 \\
\hline Fazenda do Banheiro & Arroio Grande & $\begin{array}{l}32^{\circ} 15^{\prime} 34^{\prime \prime} \mathrm{S} \\
53^{\circ} 12^{\prime} 29^{\prime \prime} \mathrm{W}\end{array}$ & 75 & PSRG & Nov 2007 \\
\hline Fazenda Nova II & Jaguarão & $\begin{array}{l}32^{\circ} 22^{\prime} 45^{\prime \prime} \mathrm{S} \\
53^{\circ} 19^{\prime} 36 ” \mathrm{~W}\end{array}$ & 85 & PSRG & Dec 2008 \\
\hline
\end{tabular}


eucalyptus stands. Thirty species were shared between treatments, 27 were recorded solely in grasslands, and 24 occurred only in afforestation stands (Tab. II). The difference in composition between assemblages was significant $(p=0.0001)$, with afforestation explaining $22 \%$ of the total variation.

Of the 81 species recorded in both treatments, nine were considered grassland specialists (species negatively affected), six were eucalyptus afforestation specialists (species positively affected) and 13 were generalists
(Tab. II). Approximately $65 \%$ of the species were too rare to classify. Among grassland specialists, six species were recorded solely in grasslands. Three afforestation specialists were detected only in eucalyptus stands. Roughly half of the 40 grassland obligate and facultative birds were absent from eucalyptus plantations (Tab. II).

Xolmis dominicanus (Vieillot, 1823), listed as vulnerable, was the only threatened species recorded. Rhea americana (Linnaeus, 1758) and Cyanocorax caeruleus (Vieillot, 1818) are considered "near-threatened".

Tab. II. Classification of bird species recorded in southern Brazilian grasslands and eucalyptus afforestation stands in four categories based on their estimated relative abundance in both treatments. The total abundance of each species in both treatments is given. A single asterisk denotes obligate grassland birds, while two asterisks indicate facultative grassland birds (sensu VicKeRY et al., 1999).

\begin{tabular}{|c|c|c|c|}
\hline Category & Scientific name & Grassland & Eucalyptus \\
\hline \multirow{9}{*}{ Grassland specialists } & Sicalis luteola* & 89 & 0 \\
\hline & Tyrannus savana* & 80 & 7 \\
\hline & Pseudoleistes virescens** & 68 & 0 \\
\hline & Vanellus chilensis* & 58 & 0 \\
\hline & Molothrus bonariensis** & 57 & 0 \\
\hline & Anthus hellmayri* & 55 & 1 \\
\hline & Geositta cunicularia* & 21 & 0 \\
\hline & Sicalis flaveola & 21 & 1 \\
\hline & Colaptes campestris** & 19 & 0 \\
\hline \multirow{6}{*}{ Afforestation specialists } & Zonotrichia capensis** & 82 & 134 \\
\hline & Leptotila verreauxi & 0 & 14 \\
\hline & Guira guira & 2 & 13 \\
\hline & Turdus rufiventris & 0 & 13 \\
\hline & Rhynchotus rufescens* & 2 & 12 \\
\hline & Vireo olivaceus & 0 & 10 \\
\hline \multirow{13}{*}{ Generalists } & Nothura maculosa* & 38 & 16 \\
\hline & Turdus amaurochalinus & 34 & 47 \\
\hline & Ammodramus humeralis* & 31 & 6 \\
\hline & Furnarius rufus** & 29 & 15 \\
\hline & Anumbius annumbi** & 26 & 7 \\
\hline & Mimus saturninus & 24 & 4 \\
\hline & Zenaida auriculata** & 21 & 8 \\
\hline & Embernagra platensis* & 16 & 4 \\
\hline & Tyrannus melancholicus & 14 & 6 \\
\hline & Agelaioides badius** & 11 & 6 \\
\hline & Pitangus sulphuratus & 10 & 12 \\
\hline & Elaenia parvirostris & 9 & 20 \\
\hline & Troglodytes aedon & 4 & 8 \\
\hline \multirow{17}{*}{ Too rare to classify } & Xolmis cinereus $* *$ & 13 & 0 \\
\hline & Columbina talpacoti** & 12 & 4 \\
\hline & Athene cunicularia* & 12 & 0 \\
\hline & Myiopsitta monachus** & 11 & 0 \\
\hline & Xolmis dominicanus $* *$ & 11 & 0 \\
\hline & Anthus furcatus* & 11 & 0 \\
\hline & Pseudoleistes guirahuro* & 11 & 0 \\
\hline & Sturnella superciliaris* & 11 & 0 \\
\hline & Rhea americana** & 8 & 0 \\
\hline & Patagioaenas picazuro & 8 & 1 \\
\hline & Xolmis irupero** & 8 & 0 \\
\hline & Pyrocephalus rubinus & 5 & 1 \\
\hline & Pipraeidea bonariensis & 5 & 0 \\
\hline & Donacospiza albifrons** & 5 & 2 \\
\hline & Colaptes melanochloros & 4 & 0 \\
\hline & Gnorimopsar chopi** & 4 & 0 \\
\hline & Bubulcus ibis** & 3 & 0 \\
\hline
\end{tabular}


Tab. II. Continue.

\begin{tabular}{|c|c|c|c|}
\hline Category & Scientific name & Grassland & Eucalyptus \\
\hline \multirow{36}{*}{ Too rare to classify } & Milvago chimango** & 3 & 0 \\
\hline & Columbina picui** & 3 & 7 \\
\hline & Satrapa icterophrys & 3 & 0 \\
\hline & Machetornis rixosa** & 3 & 0 \\
\hline & Paroaria coronata & 3 & 2 \\
\hline & Saltator aurantiirostris & 3 & 1 \\
\hline & Molothrus rufoaxillaris** & 3 & 0 \\
\hline & Knipolegus lophotes & 2 & 0 \\
\hline & Geothlypis aequinoctialis & 2 & 1 \\
\hline & Caracara plancus** & 1 & 0 \\
\hline & Phacellodomus striaticollis & 1 & 0 \\
\hline & Camptostoma obsoletum & 1 & 2 \\
\hline & Thraupis sayaca & 1 & 0 \\
\hline & Poospiza nigrorufa** & 1 & 4 \\
\hline & Sporophila caerulescens** & 1 & 4 \\
\hline & Pyrrhura frontalis & 0 & 2 \\
\hline & Tapera naevia** & 0 & 2 \\
\hline & Hydropsalis torquata** & 0 & 2 \\
\hline & Hylocharis chrysura & 0 & 1 \\
\hline & Thamnophillus ruficapillus & 0 & 2 \\
\hline & Serpophaga subcristata & 0 & 4 \\
\hline & Phylloscartes ventralis & 0 & 1 \\
\hline & Myiophobus fasciatus & 0 & 3 \\
\hline & Lathrotriccus euleri & 0 & 6 \\
\hline & Myiodynastes maculatus & 0 & 1 \\
\hline & Myiarchus swainsoni & 0 & 3 \\
\hline & Pachyramphus polychopterus & 0 & 2 \\
\hline & Cyclarhis gujanensis & 0 & 1 \\
\hline & Cyanocorax caeruleus & 0 & 2 \\
\hline & Coereba flaveola & 0 & 1 \\
\hline & Volatinia jacarina** & 0 & 2 \\
\hline & Coryphospingus cucullatus & 0 & 6 \\
\hline & Parula pitiayumi & 0 & 1 \\
\hline & Basileuterus culicivorus & 0 & 1 \\
\hline & Basileuterus leucoblepharus & 0 & 1 \\
\hline & Sporagra magellanica & 0 & 5 \\
\hline
\end{tabular}

\section{DISCUSSION}

Our results indicate that the bird assemblages inhabiting grasslands and eucalyptus stands differed in species composition. Although we did not use 'before data', our robust sampling design and use of randomization tests enabled us to determine how much of the variation in composition between impact and reference areas was explained by natural variability and/ or differences in treatments.

Differences in composition between biotic assemblages of afforested and open areas are a characteristic feature of natural and anthropogenic afforestation in natural and man-made grasslands (CLAVIJO et al., 2005; LANTSCHNER et al., 2008). Compositional alterations in faunal assemblages reflect changes in vegetation structure, spatial distribution, and composition of plant communities that occur during the afforestation process (Samways et al., 1996; Lachance \& Lavoie, 2005; CORLEY et al., 2006; LANTSCHNER et al., 2008).
Grassland specialists - the species negatively affected by afforestation in our study system - include five grassland obligate and three grassland facultative species (sensu VICKERY et al., 1999). Another three grassland obligate species and four grassland facultative species were considered generalists, suggesting that they may be somewhat tolerant to afforestation (but see below). A grassland obligate, Rhynchotus rufescens (Temminck, 1815), and a grassland facultative, Zonotrichia capensis (Statius Muller, 1776), were considered afforestation specialists. At least in part this paradox is explained by the fact that sampling was done in the early stages of afforestation, when trees were not fully developed and small patches of grassland vegetation were still found in the stands, especially in sectors where eucalyptus saplings had died. Grassland birds recorded in eucalyptus stands were found mostly in these grassy remnants. The absence of livestock enabled grasses to grow tall in the stands, allowing grassland birds adapted to live in dense vegetation, such as $R$. rufescens and Embernagra platensis 
(Gmelin, 1789), to linger in these areas. These species are naturally rare in adjacent heavily grazed hilltop grasslands, being normally restricted to the denser swales. Furthermore, open-habitat taxa that use shrubby or arboreal vegetation for perching or nesting, such as some pigeons, ovenbirds, sparrows and finches, were also able to persist in eucalyptus stands because of the small size of the trees. We expect that most grassland birds observed in the eucalyptus stands will disappear as the fast-growing trees fully develop and grassland remnants become shaded.

Most grassland species, including all obligate and facultative taxa classified as grassland specialists, are common and widespread in the Río de la Plata Grasslands and other South American open-vegetation ecosystems (Mata et al., 2006; Ridgely \& Tudor, 2009). Despite their abundance and wide distribution, observed and predicted rates of grassland conversion in the region (Hasse, 2006; Gautreau \& Vélez, 2011; Vihervaara et al., 2012) suggest that afforestation may represent a threat at a regional scale to some of these species in the near future. At least for the threatened $X$. dominicanus, which depends on hilltop grasslands for foraging (BENCKE, 2009), tree plantations may already be an important impact. Furthermore, the overall similarity of the southern Brazilian and Uruguayan grassland avifaunas (BeLton, 1994; MATA et al., 2006; Ridgely \& TUdor, 2009) indicates that afforestation is likely to impact birds in a similar way throughout the entire campos region.

Our results also indicate that direct habitat loss resulting from afforestation has a smaller impact on threatened grassland birds than on common species. Eleven threatened grassland birds occur in the campos of southern Brazil and Uruguay (IUCN, 2011; AzPIROZ et al., 2012). Alongside $X$. dominicanus, two other globally threatened grassland birds occur in our study region: Sporophila cinnamomea (Lafresnaye, 1839) and Xanthopsar flavus (Gmelin, 1788). The latter two were observed solely in wet grasslands located in swales, which explains their absence from our hilltop samples. However, indirect effects of afforestation, such as water consumption and shading, are expected to impact wet grasslands and jeopardize the survival of threatened grassland birds within tree plantations, even though swales are not cultivated (see below).

Roughly $60 \%$ of the 103,000 ha of land acquired for afforestation in our study area was not converted, in accordance with Brazilian environmental law (which protects some landscape features and a proportion of the natural vegetation), and because natural barriers such as rocky outcrops and pronounced slopes hindered cultivation. Some of these areas were rented for cattle ranching, but most remained unused. While riverine and hillside forests cover the largest portions, wet grasslands and marshes important for threatened grassland birds predominate in some swales and floodplains, especially in the southern and western sectors of our study region. The existence of these large amounts of natural vegetation within plantations was widely used as environmental propaganda by the pulpwood industry, which merchandised them as 'conservation' areas. Recent studies have shown that the conservation value of these 'ecological networks' for grassland species is greatly limited, mostly because of habitat unsuitability (LIPSEY \& HockEY, 2010) and high rates of nest predation (ReINO et al., 2010).

Most species positively affected by afforestation and some generalists are edge or forest birds. Forest and edge birds also predominated among the species recorded solely in eucalyptus stands, including those listed in the 'too rare to classify' category. Some of these, such as Pachyramphus polychopterus (Vieillot, 1818), C. caeruleus and Basileuterus leucoblepharus (Vieillot, 1817), are strongly associated with forests in our study area and seldom observed in open vegetation. LANTSCHNER et al. (2008) also observed that afforestation in Patagonian grasslands tended to benefit woodland birds more than open-vegetation taxa.

The diversity of organisms favored by afforestation in tree plantations depends largely on landscape heterogeneity and stand complexity (LINDENMAYER \& HoBBS, 2004; BrocKerhoff et al., 2008). Plantations in our study area are comprised by non-flowering clone plants, and are managed to prevent the development of understory vegetation. Therefore, two key features that augment bird diversity in Brazilian eucalyptus plantations (WILLIS, 2003) are lacking. Forest cover is naturally restricted in our study area, further limiting the species pool able to colonize eucalyptus stands. Indeed, the majority of forest species that we recorded are common inhabitants of various forest types in southern Brazil (Belton, 1994). Most birds that we recorded in eucalyptus stands appeared to be foraging or moving through the plantations. We frequently observed individuals of $Z$. capensis, Turdus amaurochalinus Cabanis, 1850, Leptotila verreauxi Bonaparte, 1855, Turdus rufiventris Vieillot, 1818, Lathrotriccus euleri (Cabanis, 1868), and $P$. polychopterus singing in eucalyptus stands, which is an evidence of territoriality. Zonotrichia capensis was recorded nesting in grasses below eucalyptus trees, while nests of Turdus spp. and of an unidentified dove (probably $L$. verreauxi) were observed in some eucalyptus trees. We expect the proportion of forest and edge birds nesting in eucalyptus stands to increase as the trees develop.

We demonstrated that the main impact of temperate grassland afforestation on faunal assemblages is the change in composition resulting from the replacement of grassland organisms by edge and forest taxa. Although most grassland birds are common and widespread, the observed and predicted conversion rates in the campos of Brazil and Uruguay may represent an important threat to regional populations of some of these birds in the near future. At least one threatened species 
may already be experiencing population loss resulting from afforestation in our study area. Species benefiting from afforestation are common edge and forest birds throughout the region. Since plantations are managed solely for pulpwood production on very short rotation periods, habitat features that could further benefit these species are absent, decreasing the conservation value of afforested areas. Urgent awareness and action is needed to prevent further loss of temperate grasslands to afforestation in southeastern South America.

Acknowledgments. We are indebted to Valério P. Pillar and four anonymous reviewers for valuable contributions to the manuscript. Sandra M. Hartz provided insights to an earlier version of the manuscript. Janaína L. Costa, Sérgio H. V. Cruz, Andros T. Gianuca, Fabiane I. C. Santos, Rudi R. Santos and Vitor C. Vianna assisted during fieldwork and helped with data management. Cristiano A. Souza and Clarimundo A. Rohrig helped with logistics and provided information on eucalyptus management. We thank Votorantim Celulose e Papel and landowners for access to their properties. Funding was provided by Universidade Católica de Pelotas and Votorantim Celulose e Papel.

\section{REFERENCES}

Allan, D .G.; Harrison, J. A.; Navarro, R. A.; Van Wilgen, B. W. \& THOMPSON, M. W. 1997. Impact of commercial afforestation on bird populations in Mpumalanga Province, South Africa - insights from bird-atlas data. Biological Conservation 79(13):173-185.

ANDERSON, M. J. 2001. A new method for non-parametric multivariate analysis of variance. Austral Ecology 26(1):32-46.

AzPiroz, A. B.; Isacch, J. P.; Dias, R. A.; Di Giacomo, A. S.; Fontana, C. S. \& Palarea, C. M. 2012. Ecology and conservation of grassland birds in southeastern South America: a review. Journal of Field Ornithology 83(3):217-246.

BEISSINGER, S. R. 2000. Ecological mechanisms of extinction. Proceedings of the National Academy of Sciences of the United States of America 97(22):11688-11689.

Belton, W. 1994. Aves do Rio Grande do Sul, distribuição e biologia. São Leopoldo, Unisinos. 584p.

Bencke, G. A. 2009. Diversidade e conservação da fauna dos campos do sul do Brasil. In: Pillar, V. P.; Müller, S. C.; Castilhos, Z. M. S. \& JACQUES, A. V. A. eds. Campos Sulinos: conservação e uso sustentável. Brasília, Ministério do Meio Ambiente, p.101-121.

Bender, E. A.; CASE, T. J. \& Gilpin, M. E. 1984. Perturbation experiments in community ecology: theory and practice. Ecology 65(1):1-13.

Benedetti-Cecchi, L. \& Osio, G. C. 2007. Replication and mitigation of effects of confounding variables in environmental impact assessment: effect of marinas on rocky-shore assemblages. Marine Ecology Progress Series 334(1)21-35.

Berthrong, S. T.; Schadt, C. W.; PiñeIro, G. \& Jackson, R. B. 2009. Afforestation alters the composition of functional genes in soil and biogeochemical processes in South American grasslands. Applied and Environmental Microbiology 75(19):6240-6248.

Bibby, C. J.; Burgess, N. D. \& Hill, D. A. 1992. Bird census techniques. London, Academic Press. 280p.

Boldrini, I. I. 2009. A flora dos campos do Rio Grande do Sul. In: Pillar, V. P.; Müller, S. C.; Castilhos, Z. M. S. \& Jacques, A. V. A. eds. Campos Sulinos: conservação e uso sustentável. Brasília, Ministério do Meio Ambiente, p.63-77.

Brockerhoff, E. G.; Jactel, H.; Parrotta, J. A.; Quine, C. P. \& SAYER, J. 2008. Plantation forests and biodiversity: oxymoron or opportunity? Biodiversity and Conservation 17(5):925-951.

Buscardo, E.; Smith, G. F.; Kelly, D. L.; Freitas, H.; Iremomger, S.; Mitchell, F.; O’Donoghue, S. \& Mckee, A.-M. 2008. The early effects of afforestation on biodiversity of grasslands in Ireland. Biodiversity and Conservation 17(5):1057-1072.

BUtLER, S. J.; VicKeRY, J. A. \& NORRIS, K. 2007. Farmland biodiversity and the footprint of agriculture. Science 315(5810):381-384.

Carrere, R. \& Lohmann, L. 1996. Pulping the South: industrial tree plantations and the global paper economy. London, WRM/ Zed Books. 280p.
Castilhos, Z. M. S.; Machado, M. D. \& Pinto, M. F. 2009. Produção animal com conservação da flora campestre do Bioma Pampa. In: Pillar, V. P.; Müller, S. C.; Castilhos, Z. M. S. \& Jacques, A. V. A. eds. Campos Sulinos: conservação e uso sustentável. Brasília, Ministério do Meio Ambiente, p.199-205.

Chao, A. \& Lin, S. Y. 2011. Program CLAM (Classification Method). Available at $<$ http://purl.oclc.org/clam $>$. Accessed on 14 July 2011.

Chazdon, R. L.; Chao, A.; Colwell, R. K.; Lin, S.-Y.; Norden, N.; Letcher, S. G.; Clark, D. B.; Finegan, B. \& Arroyo, J. P. 2011. A novel statistical method for classifying habitat generalists and specialists. Ecology 92(6):1332-1343.

Clavijo, M. P.; Nordenstahl, M.; Gundel, P. E. \& E. Jobbágy, G. 2005. Poplar afforestation effects on grassland structure and composition in the flooding pampas. Rangeland Ecology Management 58(5):474-479.

Corley, J.; Sackmann, P.; Rusch, V.; Bettinelli, J. \& Paritsis, J. 2006. Effects of pine silviculture on the ant assemblages (Hymenoptera: Formicidae) of the Patagonian steppe. Forest Ecology and Management 222(1-3):162-166.

Develey, P. F.; Setubal, R. B.; Dias, R. A. \& Bencke, G. A. 2008. Conservação das aves e da biodiversidade no bioma Pampa aliada a sistemas de produção animal. Revista Brasileira de Ornitologia 16(4):308-315.

Gautreau, P. \& Vélez, E. 2011. Strategies of environmental knowledge production facing land use changes: Insights from the Silvicultural Zoning Plan conflict in the Brazilian state of Rio Grande do Sul. Cybergeo: European Journal of Geography [on line], Environnement, Nature, Paysage, article 577. Available at $<\mathrm{http}: / /$ cybergeo.revues.org/24881>. Accessed on 05 September 2012

Glasby, T. M. 1997. Analysing data from post-impact studies using asymmetrical analyses of variance: a case study of epibiota on marinas. Australian Journal of Ecology 22(4):448-459.

Groom, M. J. \& Vynne, C. H. 2006. Habitat degradation and loss. In: Groom, M. J.; Mefre, G. K. \& Carroll, C. R. eds. Principles of Conservation Biology. Sunderland, Sinauer Associates, p.173-212.

Hasse, G. 2006. Eucalipto: histórias de um imigrante vegetal. Porto Alegre, JÁ Editores. 128p.

Henwood, W. D. 2010. Toward a strategy for the conservation and protection of the world's temperate grasslands. Great Plains Research 20(1):121-134.

HURLBERT, S. H. 1984. Pseudoreplication and the design of ecological field experiments. Ecological Monographs 54(2):187-211.

IBGE (Instituto Brasileiro de Geografia e Estatística). 1986. Folha SH.22 Porto Alegre e parte das Folhas SH. 21 Uruguaiana e SI.22 Lagoa Mirim: geologia, geomorfologia, pedologia, vegetação, uso potencial da terra. (Levantamento de Recursos Naturais, 33). Rio de Janeiro, IBGE. 791p.

IUCN (International Union for Conservation of Nature). 2011. IUCN Red List of Threatened Species. Version 2011.2. Available at $<\mathrm{http}: / /$ www.iucnredlist.org $>$. Accessed on 01 April 2012.

LaChance, D. \& Lavoie, C. 2005. The impact of peatland afforestation on plant and bird diversity in southeastern Québec. Écoscience 12(2): 161-171

Lantschner, M.; Rusch, V. \& Peyrou, C. 2008. Bird assemblages in pine plantations replacing native ecosystems in NW Patagonia. Biodiversity and Conservation 17(5):969-989.

LindenmaYeR, D. B. \& HobBs, R. J. 2004. Fauna conservation in Australian plantation forests - a review. Biological Conservation 119(2):151-168.

Lipsey, M. K. \& Hockey, P. A. R. 2010. Do ecological networks in South African commercial forests benefit grassland birds? A case study of a pine plantation in KwaZulu-Natal. Agriculture, Ecosystems \& Environment 137(1-2):133-142.

Mata, J. R. R.; Erize, F. \& Rumboll, M. 2006. A field guide to the birds of South America. London, Harper Collins. 384p.

Noss, R.; Csuti, B. \& Groom, M. J. 2006. Habitat fragmentation. In: Groom, M. J.; Mefre, G. K. \& Carroll, C. R. eds. Principles of Conservation Biology. Sunderland, Sinauer Associates, p.213-251.

Overbeck, G. E.; Müller, S. C.; Fidelis, A.; Pfadenhauer, J.; Pillar, V. D.; Blanco, C. C.; Boldrini, I. I.; Both, R. \& ForNECK, E. D. 2007. Brazil's neglected biome: The South Brazilian Campos. Perspectives in Plant Ecology, Evolution and Systematics 9(1):101-116. 
Owens, I. P. F. \& Bennett, P. M. 2000. Ecological basis of extinction risk in birds: Habitat loss versus human persecution and introduced predators. Proceedings of the National Academy of Sciences of the United States of America 97(22):12144-12148.

Pillar, V. D. 2007. MULTIV; multivariate exploratory analysis, randomization testing and bootstrap resampling; user's guide, v. 2.5. Departamento de Ecologia, UFRGS, Porto Alegre. Available at $<$ http://ecoqua.ecologia.ufrgs.br/>. Accessed on 14 July 2011.

Pillar, V. D. \& OrlócI, L. 1996. On randomization testing in vegetation science: multifactor comparisons of relevé groups. Journal of Vegetation Science 7(4):585-592.

Reino, L.; Porto, M.; Morgado, R.; Carvalho, F.; Mira, A. \& BEJA, P. 2010. Does afforestation increase bird nest predation risk in surrounding farmland? Forest Ecology and Management 260(8):1359-1366.

Remsen, J. V., Jr.; Cadena, C. D.; Jaramillo, A.; Nores, M.; Pacheco, J. F.; Pérez-Emán, J.; Robbins, M. B.; Stiles, F. G.; Stotz, D. F. \& Zimmer, K. J. 2011. A classification of the bird species of South America. American Ornithologists' Union. Available at $<$ http://www.museum.lsu.edu/ Remsen/SACCBaseline.html $>$. Accessed on 01 April 2012.

Ridgely, R. S. \& Tudor, G. 2009. Field guide to the songbirds of South America: The Passerines. Austin, University of Texas Press. 736p.

Samways, M. J.; Caldwell, P. M. \& Osborn, R. 1996. Groundliving invertebrate assemblages in native, planted and invasive vegetation in South Africa. Agriculture, Ecosystems \& Environment 59(1-2):19-32.

Soriano, A.; León, R. J. C.; Sala, O. E.; Lavado, R. S.; Deregibus, V. A.; Cahuepé, M. A.; Scaglia, O. A.; Velazquez, C. A. \&
Lemcoff, J. H. 1992. Río de la Plata grasslands. In: Coupland, R. T. ed. Ecosystems of the world 8A. Natural grasslands. New York, Elsevier, p.367-407.

Underwood, A. J. 1994. On Beyond BACI: sampling designs that might reliably detect environmental disturbances. Ecological Applications 4(1):3-15.

1997. Experiments in ecology: their logical design and interpretation using analysis of variance. Cambridge, Cambridge University Press. 524p.

Vega, E.; Baldi, G.; Jobbágy, E. G. \& Paruelo, J. M. 2009. Land use change patterns in the Río de la Plata grasslands: the influence of phytogeographic and political boundaries. Agriculture, Ecosystems \& Environment 134(3-4):287-292.

Vickery, P. D.; Tubaro, P. L.; Da Silva, J. M. C.; Peterjohn, B. G.; Herkert, J. R. \& Cavalcanti, R. B. 1999. Introduction: conservation of grassland birds in the Western Hemisphere. In Vickery, P. D. \& Herkert, J. R. eds. Ecology and conservation of grassland birds of the Western Hemisphere. Lawrence, Cooper Ornithological Society. (Studies in Avian Biology, 19), p.2-26.

VihervaAra, P.; Marjokorpi, A.; Kumpula, T.; Walls, M. \& KAMPPINEN, M. 2012. Ecosystem services of fast-growing tree plantations: A case study on integrating social valuations with land-use changes in Uruguay. Forest Policy and Economics 14(1):58-68.

Wiens, J. A. \& PARKeR, K. R. 1995. Analyzing the effects of accidental environmental impacts: approaches and assumptions. Ecological Applications 5(4):1069-1083.

WiLlis, E. O. 2003. Birds of a eucalyptus woodlot in interior São Paulo. Brazilian Journal of Biology 63(1):141-158. 